\title{
LITERATURE REVIEW OF BLOCKCHAIN TECHNOLOGY AND ITS IMPACTS AND CHALLENGES IN PRACTICE
}

\author{
Sebnem Indap ${ }^{1}$ and Prof. Dr. Mehmet Tanyas ${ }^{2}$ \\ ${ }^{1} \mathrm{PhD}$. Student, Logistics and Supply Chain Management, Maltepe University, Istanbul, Turkey \\ ${ }^{2}$ International Trade and Logistics Management Department, Istanbul, Turkey
}

DOI: http://dx.doi.org/10.38193/IJRCMS.2021.3511

\begin{abstract}
Purpose: It's aimed to provide various suggestions for the implementation of Blockchain technology in supply chain management.

Methodology: Blockchain technology and its applications in different industries are examined with the method of literature review.

Findings: There are many industries where Blockchain technology can be applied. Although it's is expected to bring many benefits to traditional supply chains, it's difficult and expensive to implement. Practical implications: To reduce barriers, governments should make more investments in research, education and training to prove and demonstrate the potential benefits.

Originality: This study is important in terms of contributing to the literature by examining the application areas in different sectors together with business effects and application difficulties and making suggestions for blockchain technology adoption.
\end{abstract}

KEYWORDS: Blockchain (BC), Blockchain Technology (BCT), Smart Contract, Supply Chain Management (SCM)

Jel Code: N7, O14, O32, O33

\section{INTRODUCTION}

Blockchain technology is a decentralized data storage method where transactions can be carried out securely without an intermediary or an authority, and where data cannot be deleted, changed or lost (Gerdan, 2019:4).

The first blockchain was conceptualized with the article titled "Bitcoin: End-to-End Electronic Cash System" published under the pseudonym Satoshi Nakamoto on October 30, 2008, and the production conditions of Bitcoin were determined with the initial block produced on January 3, 2009. Satoshi Nakamato proposed Bitcoin as a digital currency that has no physical copies. Bitcoin has been the first digital currency to solve the double spending problem, which can be used as a payment tool with Blockchain technology without the need for a central system and any intermediary (BCTR, 2019:8). 
The first application of blockchain technology is Bitcoin, an end-to-end electronic cash system. With Bitcoin, electronic money is sent between two parties without a bank or any payment institution intermediary. Later, blockchain technology has evolved into smart contracts with the ability to provide transparency and trust in the system (Zhao et al., 2019:88).

Blockchain 1.0 can be referred to as the digital currency phase, which includes cryptocurrencies with applications such as money transfer and digital payment. Blockchain 2.0, on the other hand, covers a wide range of economic and financial applications beyond simple payments and money transfer transactions and can also be called the digital economy. Blockchain 3.0, also called digital society, covers the fields of science, art, health, education, communication, management and control (Tanriverdi et al., 2019:205).

The global blockchain market size is expected to increase from 3 billion USD in 2020 to 39.7 billion USD by 2025, with a growth rate of 67.3\% in the period 2020-2025 (MarketsandMarkets, 2020).

This study is important in terms of contributing to the literature on the subject by examining the application areas in different sectors together with business effects and application difficulties in order to show that blockchain technology does not only consist of cryptocurrencies, and making suggestions for the adoption of blockchain technology.

In the second part of the study, the working mechanism and features of Blockchain technology were discussed. In the third part, the Literature Review was summarized, and the applications, effects and application difficulties of smart contracts and blockchain technology in different sectors were discussed. As a result, various suggestions have been made for the application of Blockchain Technology in supply chain management.

\section{THEORETICAL BACKGROUND}

\subsection{Blockchain Working Mechanism and Features}

A blockchain consists of a chain of cryptographically linked blocks containing aggregated transactions. Each transaction is made into a block shortly after it occurs. These blocks are mathematically chained together. Blocks are validated and managed by network nodes (computers or users participating in a blockchain network) via a shared management protocol. Each node contains a complete record of all transactions ever recorded in that blockchain. A single node cannot modify or delete a block. Nodes collectively agree on valid transactions to be included in blocks through a consensus mechanism (World Economic Forum, 2019:8).

Figure 1 illustrates the working mechanism of a blockchain system and the process from creating a 
transaction to verify it and adding the transaction to the blockchain.

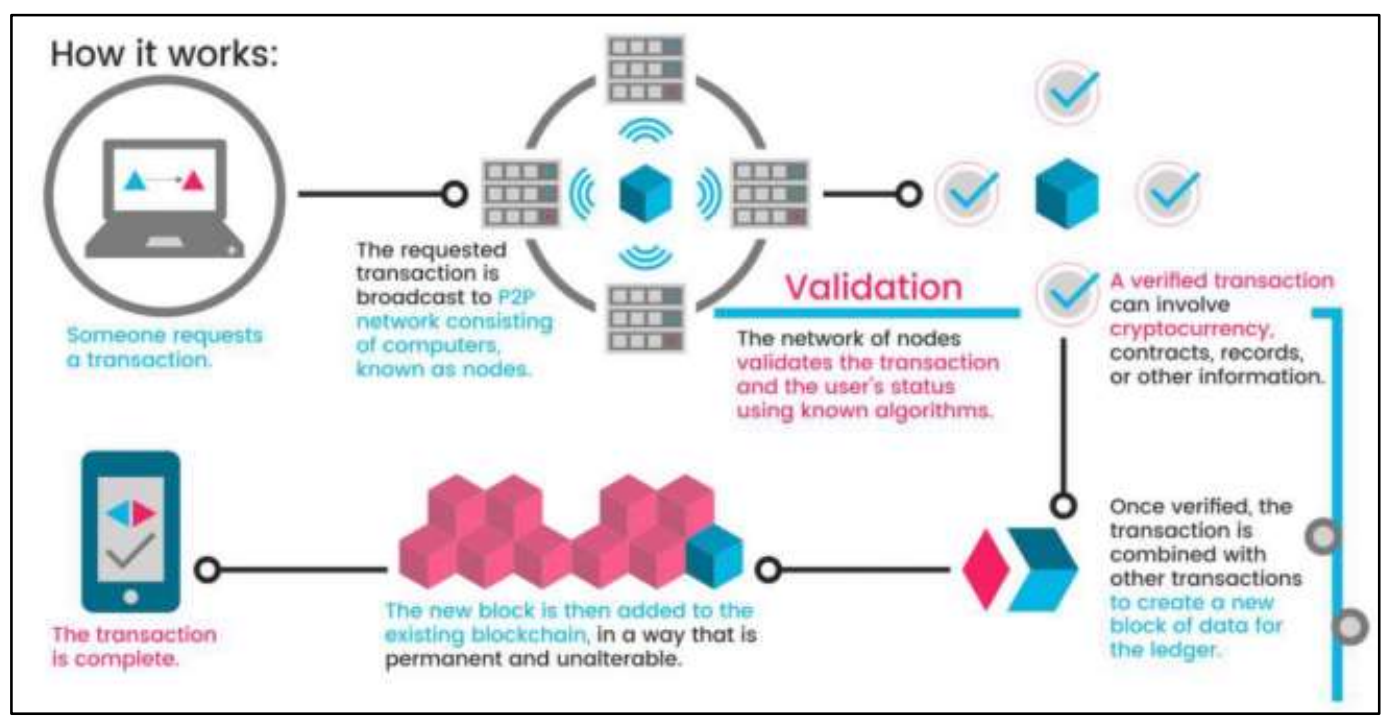

Figure 1. Blockchain Working Mechanism (Blasetti, 2017)

The key blockchain features are explained in Table 1.

\section{Table 1. Blockchain Features}

\begin{tabular}{|l|l|}
\hline Anonymity \& Privacy & $\begin{array}{l}\text { The blockchain uses a cryptographic private key that provides data } \\
\text { privacy and anonymity. Blockchain technology ensures data } \\
\text { security without compromising the privacy of stakeholders } \\
\text { (Kamble et al., 2019:3). }\end{array}$ \\
\hline Auditability & $\begin{array}{l}\text { No special authorization is required to audit transactions on the } \\
\text { blockchain and it can be accessed by all participants such as } \\
\text { institutions, regulators and consumers (Kamble et al., 2019:4). } \\
\text { Depending on the technology and the use of cryptographic } \\
\text { techniques, it can often be designed what information is presented } \\
\text { to whom. This increases auditability, builds trust and reduces fraud } \\
\text { (World Economic Forum, 2019:9). }\end{array}$ \\
\hline Decentralization & $\begin{array}{l}\text { In a traditional centralized transaction system, a central trusted } \\
\text { institution such as a bank must verify every transaction. This } \\
\text { process can cause cost and performance bottlenecks on central } \\
\text { servers. With Blockchain technology, transactions within the } \\
\text { blockchain network can be performed between two users without }\end{array}$ \\
\hline
\end{tabular}




\begin{tabular}{|l|l|}
\hline & $\begin{array}{l}\text { the need for authentication by a single central authority or } \\
\text { intermediary (Olsen et al., 2019:9). }\end{array}$ \\
\hline Distributed Trust & $\begin{array}{l}\text { The distributed trust mechanism means that the need for trust in a } \\
\text { central authority is eliminated. Two peers can transact between } \\
\text { each other without the need to trust a third party (Gerdan, } \\
\text { 2019:25). }\end{array}$ \\
\hline Immutability & $\begin{array}{l}\text { In the blockchain, records are stored in interconnected blocks. Any } \\
\text { change to the historical records would break the entire blockchain } \\
\text { structure. This means that historical data cannot be changed } \\
\text { without warning other users and prevents human interference of } \\
\text { the records (Zhang et al., 2019:3). } \\
\text { The blockchain consensus algorithm can ensure data security. } \\
\text { Users review transactions. When decentralization eliminates } \\
\text { centralized power in the network, it also prevents disruption of a } \\
\text { supply chain due to a single point of failure, it does not cause the } \\
\text { entire network to fail, which can reduce the likelihood of hacking } \\
\text { (Zhang et al., 2019:3). }\end{array}$ \\
\hline $\begin{array}{l}\text { Exact copy of records at every node in the blockchain enables real- } \\
\text { time inspection and review of data, providing transparency } \\
\text { (Y1lmaz, 2019:27). }\end{array}$ \\
\hline Transparency
\end{tabular}

\subsection{Smart Contracts}

A smart contract is a computerized transaction protocol that automatically executes the terms of a contract on a blockchain after predefined conditions are met. Blockchains can be programmed to automate business processes, for example making payments (World Economic Forum, 2020:234). A smart contract is similar to a regular contract, but it is executed or enforced when certain conditions are met without the need for human interaction. Since the contract is automatically executed on the Blockchain, it removes the uncertainties between the parties when the conditions are met. It reduces costs by eliminating paperwork and third-party involvement. It eliminates the need for trust and the risk of loss between parties (Croxson et al., 2019:98-99).

The use of smart contracts can have legal consequences, particularly with regard to applicability. Paper systems were reported to cost $\$ 18$ trillion per year globally in 2014, and smart contracts offer significant opportunities to reduce costs and increase reliability (European Commission, 2020:160). More than 200 blockchain experts were asked about the factors affecting the use of smart contracts in the blockchain and the results in Figure 2 were obtained. In addition to providing integration across industries, ease of use, cost savings and efficiency advantages; providing legal certainty is seen as the most important factor affecting the use of smart contracts. 


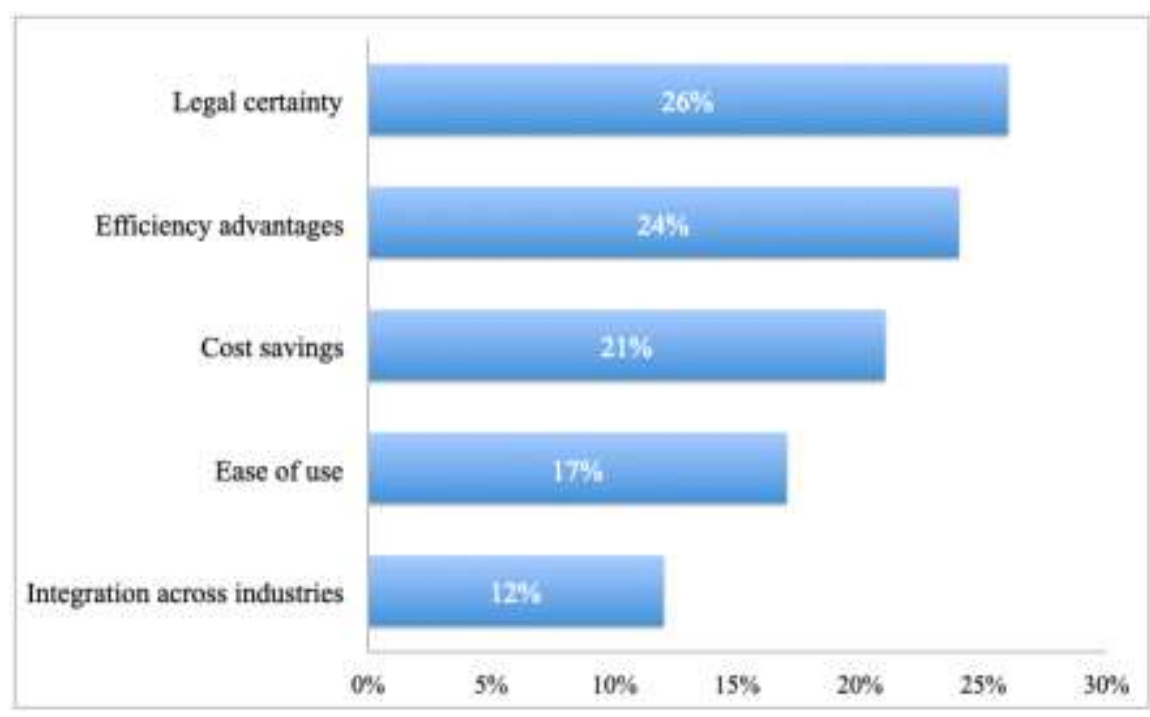

Figure 2. Factors Affecting the Use of Smart Contracts on the Blockchain (European Commission, 2020:140)

Smart contracts can significantly reduce transaction costs and increase the efficiency and transparency of transactions. For example, grain exports have a complex network of intermediaries with many stakeholders including farmers, wholesalers and buyers, as well as shipping, warehousing, quality control, port, customs, financing, contracting and authentication services. At each stage of this value chain, products must be stored, processed and transported at special standards such as humidity and temperature. In the global value chain exemplified in Figure 3, transaction costs and paperwork can be reduced with Blockchain and smart contracts. Blockchain technology can reduce or eliminate the need for intermediaries along the value chain (FAO, 2020:114-15).

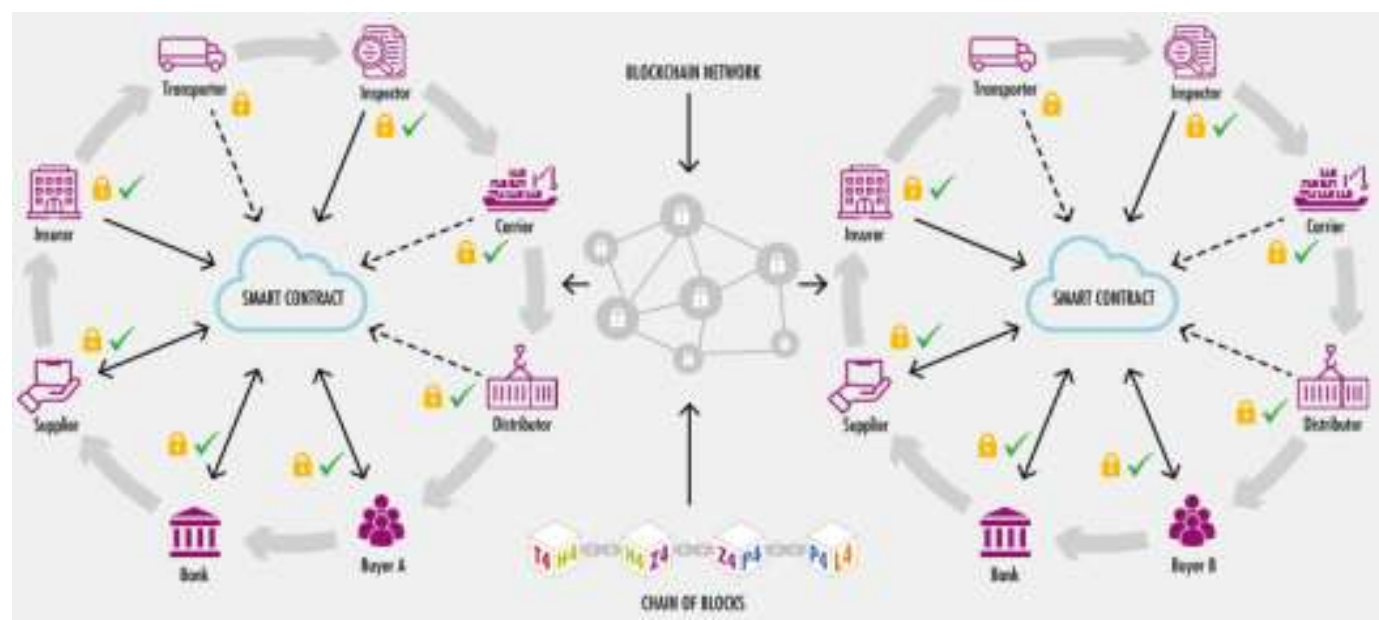

Figure 3. Blockchain Based Agri-Food Value Chain Example (FAO, 2020:116) 


\section{Methodology - Literature Review}

Academic resources between 2010-2019 were reviewed with the keywords "Blockchain", "Blockchain Technology", "Smart Contract", and "Supply Chain Management" in Web of Science, Scopus, Science Direct, Google Scholar and YÖK National Thesis Center databases.

A total of 91 studies were accessed, first non-English or non-Turkish sources and then technicaloriented sources were excluded, and the summaries of 79 sources which were identified were reviewed in terms of their relevance to the scope of the study.

21 studies were selected to be examined in detail to ensure diversity in research topics and the examined sectors and sub-sectors. These studies, which are examined on Blockchain applications in different sectors, are shown in Table 2 along with research types and methods.

Table 2 Literature Review

\begin{tabular}{|c|c|c|c|c|}
\hline No & Author, Year & Research Type & Method & Sector \\
\hline \multirow{4}{*}{1} & Amir Latif et al., 2019 & Conference Paper & Conceptual Study & Retail \\
\hline & Title & \multicolumn{3}{|c|}{$\begin{array}{l}\text { Blockchain Transforms the Retail Level by Using a Supply Chain Rules and } \\
\text { Regulation }\end{array}$} \\
\hline & Keywords & \multicolumn{3}{|c|}{$\begin{array}{l}\text { Blockchain (BC); Ethereum; Hash; Loyalty; Retail; Smart Contract; Trusted- } \\
\text { Retail }\end{array}$} \\
\hline & Summary & \multicolumn{3}{|c|}{$\begin{array}{l}\text { How Blockchain technology }(\mathrm{BCT}) \text { can be applied in the retail sector, its } \\
\text { benefits and some important features are discussed. }\end{array}$} \\
\hline \multirow{4}{*}{2} & Andoni et al., 2019 & Article & $\begin{array}{l}\text { Literature Review, } \\
\text { Use Case Analysis }\end{array}$ & Energy \\
\hline & Title & \multicolumn{3}{|c|}{$\begin{array}{l}\text { Blockchain technology in the energy sector: A systematic review of challenges } \\
\text { and opportunities }\end{array}$} \\
\hline & Keywords & \multicolumn{3}{|c|}{$\begin{array}{l}\text { Blockchain; Distributed Ledger; Energy Decentralization; Peer-to-peer Energy } \\
\text { Trading; Prosumer; Renewable Energy }\end{array}$} \\
\hline & Summary & \multicolumn{3}{|c|}{$\begin{array}{l}\text { The basic principles of BCT are explained and the focus is on Blockchain } \\
\text { solutions for the energy sector. Literature and current business cases were } \\
\text { reviewed. Opportunities and potential challenges are discussed. }\end{array}$} \\
\hline \multirow{4}{*}{3} & Azzi et al., 2019 & Article & $\begin{array}{l}\text { Literature Review, } \\
\text { Case Study }\end{array}$ & Supply Chain \\
\hline & Title & \multicolumn{3}{|c|}{ The power of a blockchain-based supply chain } \\
\hline & Keywords & \multicolumn{3}{|c|}{$\begin{array}{l}\text { Blockchain; Supply Chain Management; Traceability Systems; Decentralized } \\
\text { Systems }\end{array}$} \\
\hline & Summary & \multicolumn{3}{|c|}{$\begin{array}{l}\text { This study explains how BC can be integrated into the supply chain } \\
\text { architecture to create a reliable, transparent, authentic and secure system. }\end{array}$} \\
\hline
\end{tabular}




\begin{tabular}{|c|c|c|c|c|}
\hline \multirow[t]{2}{*}{$\mathbf{N}$} & \multirow[t]{2}{*}{ Author, Year } & Research Type & \multirow{2}{*}{\multicolumn{2}{|c|}{$\begin{array}{l}\text { Method Sector } \\
\text { lies and real-world applications, the benefits of } \\
\text { in in the supply chain and the challenges faced in } \\
\text { y chain management are examined. }\end{array}$}} \\
\hline & & \multirow{2}{*}{\multicolumn{3}{|c|}{$\begin{array}{l}\text { Through theoretical studies and real-world applications, the benefits of } \\
\text { implementing Blockchain in the supply chain and the challenges faced in } \\
\text { Blockchain-based supply chain management are examined. } \\
\text { Article } \quad \text { Literature Review } \quad \text { Land Management }\end{array}$}} \\
\hline & Bennett et al., 2019 & & & \\
\hline & Title & \multicolumn{3}{|c|}{$\begin{array}{l}\text { Transformations, transitions, or tall tales? A global review of the uptake and } \\
\text { impact of NoSQL, blockchain, and big data analytics on the land } \\
\text { administration sector }\end{array}$} \\
\hline & Keywords & \multicolumn{3}{|c|}{$\begin{array}{l}\text { Cadastre; Distributed Databases; Land Registration; Land Administration; } \\
\text { Unstructured Data }\end{array}$} \\
\hline & Summary & \multicolumn{3}{|c|}{$\begin{array}{l}\text { In this article, it is aimed to give an idea about the opportunities, challenges, } \\
\text { impacts and future scenarios related to the application of emerging } \\
\text { technologies by examining international cases in the land sector. }\end{array}$} \\
\hline & $\begin{array}{l}\text { Biswas and Gupta, } \\
2019\end{array}$ & Article & $\begin{array}{l}\text { DEMATEL, } \\
\text { Barrier Analysis }\end{array}$ & Industry and Service \\
\hline & Title & \multicolumn{3}{|c|}{ Analysis of barriers to implement blockchain in industry and service sectors } \\
\hline & Keywords & \multicolumn{3}{|c|}{$\begin{array}{l}\text { Blockchains; Digital Ledger Technology; DEMATEL; Barrier analysis; Causal } \\
\text { Relationship }\end{array}$} \\
\hline & Summary & \multicolumn{3}{|c|}{$\begin{array}{l}\text { Barriers to the adoption and successful implementation of BC in industry and } \\
\text { service sectors were investigated using the DEMATEL technique. Obstacles } \\
\text { identified with the help of existing literature and expert opinions were } \\
\text { categorized and ranked according to their importance. High sustainability costs } \\
\text { have been identified as the most important barrier to BC adoption. }\end{array}$} \\
\hline & Casino et al., 2019 & Article & Modeling & Food Supply Chain \\
\hline & Title & \multicolumn{3}{|c|}{ Modeling food supply chain traceability based on blockchain technology } \\
\hline & Keywords & \multicolumn{3}{|c|}{ Applications; Blockchain; Classification } \\
\hline & Summary & \multicolumn{3}{|c|}{$\begin{array}{l}\text { The study aimed to develop a distributed functional model to provide } \\
\text { decentralized and automated food supply chain traceability based on BCT and } \\
\text { smart contracts. To evaluate the feasibility of the proposed modeling approach, } \\
\text { a food traceability use-scenario is presented. The applicability of the model is } \\
\text { explained by the development of a fully functional smart contract and a local } \\
\text { custom BC. The overall benefits of the proposed model were evaluated based } \\
\text { on predefined key performance indicators. }\end{array}$} \\
\hline \multirow{3}{*}{7} & Croxson et al., 2019 & Conference Pape & $\begin{array}{l}\text { Questionnaire, } \\
\text { Q-Method }\end{array}$ & Food Supply Chain \\
\hline & Title & \multicolumn{3}{|c|}{ Making Sense of Blockchain in Food Supply-Chains } \\
\hline & Keywords & \multicolumn{3}{|c|}{ Value Chain; Trust-less Platform; Q-Methodology; Precision Food Systems } \\
\hline
\end{tabular}




\begin{tabular}{|c|c|c|c|c|}
\hline \multirow[t]{2}{*}{ No } & Author, Year & Research Type & Method & Sector \\
\hline & Summary & \multicolumn{3}{|c|}{$\begin{array}{l}\text { Q-methodology was used to examine whether BCT could be the solution for } \\
\text { accurate tracking and tracing of products in New Zealand agricultural industry. } \\
\text { Empirical research has revealed } 4 \text { distinct groups in the industry with different } \\
\text { BC perspectives and potential. The results showed that although industry } \\
\text { experts believed the implementation of BC was inevitable and would solve } \\
\text { current problems, factors such as high installation costs and complexity of } \\
\text { technology could be barriers. Further research has been proposed on how to } \\
\text { solve food safety problems with new technologies such as BC, IoT (internet of } \\
\text { things) and AI (artificial intelligence). }\end{array}$} \\
\hline \multirow{4}{*}{8} & Galvez et al., 2018 & Article & $\begin{array}{l}\text { Literature Review, } \\
\text { Case Study }\end{array}$ & Food \\
\hline & Title & \multicolumn{3}{|c|}{ Future challenges on the use of blockchain for food traceability analysis } \\
\hline & Keywords & \multicolumn{3}{|c|}{$\begin{array}{l}\text { Blockchain; Agricultural \& Farming Applications; Food Chain; Food } \\
\text { Authentication; Traceability; Data Analysis and Management }\end{array}$} \\
\hline & Summary & \multicolumn{3}{|c|}{$\begin{array}{l}\text { One way to solve traceability issues and ensure transparency is to use BCT to } \\
\text { store data in chemical analysis in chronological order so that it is impossible to } \\
\text { manipulate later. The potential of BCT to provide traceability and authenticity } \\
\text { in the food supply chain has been examined. Although achieving food } \\
\text { traceability with BCT seems promising, the limits to consider are outlined. }\end{array}$} \\
\hline \multirow{4}{*}{9} & Gerdan, 2019 & Master Thesis & $\begin{array}{l}\text { Modeling, Prototype \& } \\
\text { Interface Design }\end{array}$ & Food - Eggs \\
\hline & Title & \multicolumn{3}{|c|}{$\begin{array}{l}\text { Food Safety with Blockchain Technology and an Example Application for the } \\
\text { Egg Industry }\end{array}$} \\
\hline & Keywords & \multicolumn{3}{|c|}{$\begin{array}{l}\text { Blockchain Technology; Food safety; Food Traceability; Supply Chain; Egg } \\
\text { Production; User Interface Design }\end{array}$} \\
\hline & Summary & \multicolumn{3}{|c|}{$\begin{array}{l}\text { The innovations that BCT will bring to the food supply chain traceability and } \\
\text { the advantages it offers have been researched and the benefits it will bring to } \\
\text { food safety have been examined. An organic egg producer under the name of } \\
\text { Ecological Egg Ltd. was designed to be examined. A digital platform using } \\
\text { BCT called Blockchain Lab. was assumed and a food safety solution prototype } \\
\text { was created for the egg producer and sample user interfaces were designed. }\end{array}$} \\
\hline \multirow{4}{*}{10} & Hancock, 2019 & Report & Questionnaire & Food - Beef \\
\hline & Title & \multicolumn{3}{|c|}{$\begin{array}{l}\text { The Integration of Blockchain Technology to the Beef Industry-A Comparative } \\
\text { Analysis }\end{array}$} \\
\hline & Keywords & \multicolumn{3}{|c|}{$\begin{array}{l}\text { Blockchain; Beef Industry; Cattle Industry; Supply Chain Optimization; } \\
\text { Supply Chain Transparency; Meat Industry; Food Traceability; Ranching; } \\
\text { Agribusiness }\end{array}$} \\
\hline & Summary & \multicolumn{3}{|c|}{$\begin{array}{l}\text { It is aimed to investigate Blockchain applications in the beef industry in the } \\
\text { USA and Kenya. Previous studies have not focused on differences between }\end{array}$} \\
\hline
\end{tabular}




\begin{tabular}{|c|c|c|c|c|}
\hline No & Author, Year & Research Type & Method & Sector \\
\hline & & $\begin{array}{l}\text { countries, this stu } \\
\text { The primary resea } \\
\text { various stakehold } \\
\text { opportunities. } \\
\text { It has been found } \\
\text { broadly advisable } \\
\text { regulatory envirol }\end{array}$ & $\begin{array}{l}\text { ed to address this gap. } \\
\text { thod was applied as the } m \\
\text { he industry about supply } \\
\text { e integration of Blockchai } \\
\text { aries greatly depending on } \\
\text { of industries at different ce }\end{array}$ & $\begin{array}{l}\text { n method, by interviewing } \\
\text { in issues and } \\
\text { nto the beef industry is } \\
\text { ne developmental stage and } \\
\text { ntries. }\end{array}$ \\
\hline & Kamble et al., 2019 & Article & $\begin{array}{l}\text { ISM, } \\
\text { DEMATEL }\end{array}$ & Agriculture \\
\hline & Title & Modeling the bloc & enabled traceability in ag & culture supply chain \\
\hline 11 & Keywords & $\begin{array}{l}\text { Blockchain Techn } \\
\text { Traceability; Tran }\end{array}$ & $\begin{array}{l}\text { Agriculture; Supply Chai } \\
\text { cy; ISM; DEMATEL }\end{array}$ & Sustainability; \\
\hline 11 & Summary & $\begin{array}{l}\text { In this study, the } 1 \\
\text { Blockchain Techr } \\
\text { The findings shov } \\
\text { important reason } \\
\text { agriculture supply }\end{array}$ & $\begin{array}{l}\text { ships between the factors } \\
\text { in the agriculture supply c } \\
\text { Imong the factors identifie } \\
\text { implementation of Blockc } \\
\text {, followed by auditability }\end{array}$ & $\begin{array}{l}\text { abling the adoption of } \\
\text { in were determined. } \\
\text { traceability is the most } \\
\text { in Technology in the } \\
\text { dimmutability. }\end{array}$ \\
\hline & Kamilaris et al., 2018 & Report & Multiple Case Study & Agriculture- Food \\
\hline & Title & The Rise of the B & ain Technology in Agricul & re and Food Supply Chain \\
\hline & Keywords & Blockchain Techr & Agriculture; Food Supply & Chain \\
\hline 12 & Summary & $\begin{array}{l}\text { This article exami } \\
\text { and food supply c } \\
\text { discusses the gen } \\
\text { The findings shov } \\
\text { food supply chain } \\
\text { wider popularity a }\end{array}$ & $\begin{array}{l}\text { impact of Blockchain Te } \\
\text { resents current ongoing pr } \\
\text { plications, challenges and } \\
\text { lockchain is a promising } \\
\text { lany barriers and challeng } \\
\text { farmers and systems. }\end{array}$ & $\begin{array}{l}\text { nology in the agriculture } \\
\text { ects and initiatives, and } \\
\text { e potential. } \\
\text { hnology for a transparent } \\
\text { still exist that hinder its }\end{array}$ \\
\hline & $\begin{array}{l}\text { Kayıkçı and } \\
\text { Subramanian, } 2018\end{array}$ & Conference Paper & $\begin{array}{l}\text { Literature Review, } \\
\text { Modeling, Questionnaire }\end{array}$ & Food-Milk \\
\hline & Title & $\begin{array}{l}\text { Feasibility of Foo } \\
\text { Context }\end{array}$ & Reduction with Blockcha & in the Emerging Economy \\
\hline 13 & Summary & $\begin{array}{l}\text { This article analy } \\
\text { challenges of Blo } \\
\text { was conducted for } \\
\text { The results of the } \\
\text { trust in technolog. } \\
\text { are the key to red }\end{array}$ & $\begin{array}{l}\text { feasibility of reducing foc } \\
\text { n Technology. To underst } \\
\text { urkish dairy supply chain. } \\
\text { ch show that barriers such } \\
\text { dards, consumer perceptio } \\
\text { ood loss in the supply cha }\end{array}$ & $\begin{array}{l}\text { loss and the adaptation } \\
\text { d the barriers, a survey } \\
\text { trust between businesses, } \\
\text { legislation and regulation }\end{array}$ \\
\hline 14 & Kim et al., 2018 & Conference Paper & $\begin{array}{l}\text { System Design, } \\
\text { Modeling }\end{array}$ & Food \\
\hline
\end{tabular}




\begin{tabular}{|c|c|c|c|c|}
\hline \multirow[t]{4}{*}{ No } & Author, Year & Research Type & Method & Sector \\
\hline & Title & \multicolumn{3}{|c|}{$\begin{array}{l}\text { Integrating Blockchain, Smart Contract-Tokens, and IoT to Design a Food } \\
\text { Traceability Solution }\end{array}$} \\
\hline & Keywords & \multicolumn{3}{|c|}{ Blockchain; Ethereum; Smart Contract; IoT; Food Traceability; GS1 Standards } \\
\hline & Summary & \multicolumn{3}{|c|}{$\begin{array}{l}\text { The study introduces Harvest Network, a theoretical food traceability } \\
\text { application "from farm to fork" integrating Blockchain and IoT devices. The } \\
\text { aim is to create a distributed ledger accessible to all stakeholders in the supply } \\
\text { chain. A basic framework has been established to build a prototype or } \\
\text { simulation using existing technologies and protocols. }\end{array}$} \\
\hline \multirow[b]{4}{*}{1.} & Knezevic, 2018 & Article & Scenario Analysis & Finance \\
\hline & Title & \multicolumn{3}{|c|}{$\begin{array}{l}\text { Impact of Blockchain Technology Platform in Changing the Financial Sector } \\
\text { and Other Industries }\end{array}$} \\
\hline & Keywords & \multicolumn{3}{|c|}{ Blockchain; Bitcoin; Criptovalutes; Scenario } \\
\hline & Summary & \multicolumn{3}{|c|}{$\begin{array}{l}\text { The purpose of the article is to conduct research on the impact of the BCT } \\
\text { platform on finance and other industries via cryptocurrency. The results of the } \\
\text { scenario and trend analysis show that BCT currently has a profound impact on } \\
\text { the financial sector, is in the early stages of changing many sectors and will } \\
\text { change them significantly in the next } 5 \text { to } 10 \text { years. }\end{array}$} \\
\hline \multirow[b]{4}{*}{16} & Rozman et al., 2019 & Conference Pape & $\begin{array}{l}\text { Case Study, } \\
\text { Conceptual Modeling }\end{array}$ & Supply Chain \\
\hline & Title & \multicolumn{3}{|c|}{ Distributed logistics platform based on Blockchain and IoT } \\
\hline & Keywords & \multicolumn{3}{|c|}{ Blockchain; IoT; Supply Chain Management; Distributed Network; Logistics } \\
\hline & Summary & \multicolumn{3}{|c|}{$\begin{array}{l}\text { This article presents an approach to integrating BCT and IoT into modern } \\
\text { supply chains. The modular nature of the proposed new logistics platform } \\
\text { concept allows users to add their own nodes. Nodes communicate with IoT } \\
\text { technology. BCT is used not only for writing and transacting contracts, but also } \\
\text { as a reliable public listing of services and information. }\end{array}$} \\
\hline \multirow{4}{*}{17} & $\begin{array}{l}\text { Tönnissen and } \\
\text { Teuteberg, } 2019\end{array}$ & Article & $\begin{array}{l}\text { Case-Literature Review, } \\
\text { Conceptual Modeling }\end{array}$ & Supply Chain \\
\hline & Title & \multicolumn{3}{|c|}{$\begin{array}{l}\text { Analysing the impact of blockchain-technology for operations and supply } \\
\text { chain management: An explanatory model drawn from multiple case studies }\end{array}$} \\
\hline & Keywords & \multicolumn{3}{|c|}{ Disintermediation; Supply Chain; Blockchain; Explanatory Model; Case Study } \\
\hline & Summary & \multicolumn{3}{|c|}{$\begin{array}{l}\text { In this article, multiple-case analysis is used to develop an explanatory model } \\
\text { for the interaction of actors in a supply chain that includes BCT. The } \\
\text { intermediaries blockchain can replace and its impact are explained. }\end{array}$} \\
\hline \multirow[t]{2}{*}{18} & Yiannas, 2018 & Article & $\begin{array}{l}\text { Case Study, Conceptual } \\
\text { Evidence Study }\end{array}$ & Food - Mango \& Pork \\
\hline & Title & \multicolumn{3}{|c|}{ A New Era of Food Transparency Powered by Blockchain } \\
\hline
\end{tabular}




\begin{tabular}{|c|c|c|c|c|}
\hline \multirow[t]{2}{*}{ No } & Author, Year & Research Type & Method & Sector \\
\hline & Summary & \multicolumn{3}{|c|}{$\begin{array}{l}\text { Walmart and IBM presented } 2 \text { PoCs to demonstrate that Blockchain } \\
\text { Technology offers a convenient way to track and verify food from farm to store } \\
\text { quickly and precisely. PoCs are focused on the traceability and authenticity } \\
\text { element of the Blockchain solution. The time taken to view mangoes with } \\
\text { Blockchain Technology decreased from } 7 \text { days to } 2.2 \text { seconds. }\end{array}$} \\
\hline \multirow{4}{*}{19} & Y1lmaz, 2019 & Master Thesis & Modeling & Food Supply Chain \\
\hline & Title & \multicolumn{3}{|c|}{$\begin{array}{l}\text { Designing a Blockchain system that will track the delivery of products from } \\
\text { the supplier to the consumer }\end{array}$} \\
\hline & Keywords & \multicolumn{3}{|c|}{ Blockchain; Bitcoin; Nonce; Smart Contract; Supply Chain Management } \\
\hline & Summary & \multicolumn{3}{|c|}{$\begin{array}{l}\text { To solve the difficulties experienced in food supply chain management, a } \\
\text { proposal has been made regarding the use of Blockchain Technology. } \\
\text { Information about Ethereum technology and smart contracts and an example of } \\
\text { a working Blockchain is presented. }\end{array}$} \\
\hline & Zhang et al., 2019 & Conference Pape & Literature Review & Food \\
\hline & Title & \multicolumn{3}{|c|}{$\begin{array}{l}\text { A content based literature review on the application of blockchain in food } \\
\text { supply chain management }\end{array}$} \\
\hline & Keywords & \multicolumn{3}{|c|}{ Blockchain; Food Supply Chain } \\
\hline 20 & Summary & \multicolumn{3}{|c|}{$\begin{array}{l}\text { The aim of the study is to explore how Blockchain is used in the field of food } \\
\text { supply chain and how it can help address food safety issues. } \\
\text { In order to answer the following research questions, an in-depth analysis of the } \\
\text { literature was conducted to fill in the gaps: } \\
\text { 1) What are the researches on the application of Blockchain in food supply } \\
\text { chain management? } \\
\text { 2) What benefits can Blockchain bring to the food supply chain? } \\
\text { 3) What are the challenges of implementing Blockchain in the food supply } \\
\text { chain? }\end{array}$} \\
\hline & Zhao et al., 2019 & Article & $\begin{array}{l}\text { Systematic Literature } \\
\text { Network Analysis }\end{array}$ & Agriculture-Food \\
\hline & Title & \multicolumn{3}{|c|}{$\begin{array}{l}\text { Blockchain technology in agri-food value chain management: A synthesis of } \\
\text { applications, challenges and future research directions }\end{array}$} \\
\hline & Keywords & \multicolumn{3}{|c|}{$\begin{array}{l}\text { Blockchain Technology; Agri-food Value Chain Digitisation; Industry 4.0; } \\
\text { IoT; Systematic Literature Network Analysis (SLNA) }\end{array}$} \\
\hline 21 & Summary & \multicolumn{3}{|c|}{$\begin{array}{l}\text { SLNA was used to review Blockchain Technology, including key applications } \\
\text { and challenges in the agri-food value chain. } \\
\text { Blockchain Technology along with IoT, has been shown to improve agri-food } \\
\text { value chain management in } 4 \text { main aspects: traceability, information security, } \\
\text { production and sustainable water management. } \\
6 \text { challenges were identified, including high cost, storage capacity and } \\
\text { scalability, privacy leakage, regulation issue, throughput \& latency issue and } \\
\text { lack of skills. }\end{array}$} \\
\hline
\end{tabular}




\section{FINDINGS}

\subsection{Applications of Blockchain Technology in Different Industries}

Blockchain technology is not just about Bitcoin and other cryptocurrencies. There are many industries that can benefit from the application of blockchain technology, especially with the use of smart contracts. The most important ones are exemplified in Table 3.

Table 3. Applications of Blockchain Technology in Different Industries

\begin{tabular}{|l|l|}
\hline Agriculture \& Food & $\begin{array}{l}\text { Blockchain technology provides improvements in food safety programs by } \\
\text { allowing the source of a product to be identified quickly, tracing the cause of } \\
\text { a foodborne illness back to its source before it becomes a widespread } \\
\text { problem. American retail company Walmart and technology firm IBM } \\
\text { demonstrated the power of the system in 2017, using the example of mango } \\
\text { and pork. While the traceability of shipping documents and invoices for these } \\
\text { products in existing systems can take up to a week, with the use of } \\
\text { Blockchain technology the entire supply chain was traceable in a matter of } \\
\text { seconds. In addition, food waste can be reduced by monitoring the shelf life } \\
\text { of food in more detail during the transport and storage process (Yiannas, } \\
\text { 2018). }\end{array}$ \\
\hline Education & $\begin{array}{l}\text { As web-based distance learning becomes more common, so does the need } \\
\text { for an independent and transparent way to verify students' educational } \\
\text { records and transcripts. A blockchain-based platform can act as a notary for } \\
\text { educational records, providing educational institutions and employers with } \\
\text { secure access to transcripts and records, and employers the data needed to } \\
\text { determine whether the resumes of the candidates are correct (Alladi et al., } \\
\text { 2019:176947). }\end{array}$ \\
\hline Energy & $\begin{array}{l}\text { In the energy sector, automatic billing can be done with Blockchain, smart } \\
\text { contract and smart metering systems. Together with artificial intelligence } \\
\text { techniques such as machine learning, blockchain can identify consumer } \\
\text { energy patterns. In network applications, blockchain smart devices can be } \\
\text { used for communication, data transfer or storage. Smart contracts can } \\
\text { simplify and speed up switching energy suppliers. Increased market mobility } \\
\text { can increase competition and potentially lower energy tariffs. Immutable } \\
\text { records and transparent processes can significantly improve auditing and } \\
\text { compliance (Andoni et al., 2019:151-52). }\end{array}$ \\
\hline $\begin{array}{l}\text { Global money transfers are both costly and time consuming due to different } \\
\text { intermediaries. In addition, there may be problems in compliance control and } \\
\text { reporting. A new blockchain and smart contract-based process can reduce the } \\
\text { number of intermediaries, enabling the payments to be made in real time and }\end{array}$ \\
\hline Payment Systems
\end{tabular}




\begin{tabular}{|c|c|}
\hline & $\begin{array}{l}\text { at lower cost. A simplified and easily controllable structure can be created in } \\
\text { blockchain (Usta and Doğantekin, 2018:55). }\end{array}$ \\
\hline $\begin{array}{l}\text { Health \& } \\
\text { Pharmaceutical } \\
\text { industry }\end{array}$ & $\begin{array}{l}\text { Blockchain capabilities can be used to ensure the confidentiality of } \\
\text { healthcare data and patient privacy to conduct research using patient data } \\
\text { without violating confidentiality, and to increase the security of drug supply } \\
\text { chains against counterfeit drugs, which is a growing threat, especially with } \\
\text { the increase in online drug sales. Pharmaceutical supply chain and } \\
\text { pharmaceutical companies can track and verify the movement of each drug } \\
\text { using blockchain. By recording every exchange of a drug, blockchain can } \\
\text { help companies identify defective products before they reach consumers } \\
\text { (European Commission, 2020:171). }\end{array}$ \\
\hline Public Sector & $\begin{array}{l}\text { Blockchain and smart contracts can automate processes and improve } \\
\text { information sharing in the public sector. Potential uses: Birth and marriage } \\
\text { certificates, death records, digital identities such as visas and passports; } \\
\text { personal records such as health and insurance; title records, including details } \\
\text { of real estate and property transactions, and historical records; benefits and } \\
\text { rights, such as social security, medical benefits; local and international } \\
\text { donations; automatic payments via smart contracts; accurate counting and } \\
\text { control with digital voting; can be summarized as facilitating inter- } \\
\text { institutional processes (OECD, 2018:19). }\end{array}$ \\
\hline Retail & $\begin{array}{l}\text { Blockchain-based smart loyalty programs detect, store and validate } \\
\text { consumer behavior for more personalized targeting, encouraging behavior } \\
\text { and rewarding loyalty using smart contract logic, resulting in higher } \\
\text { customer satisfaction and revenue growth in the retail industry (Amir Latif } \\
\text { et al., 2019:269). Consumer surveys and research can also be conducted } \\
\text { securely using blockchain. Blockchain can be used to tag products so the } \\
\text { legal owner can be instantly where the product is if it is stolen or lost } \\
\text { (Deloitte, 2018:11). }\end{array}$ \\
\hline $\begin{array}{l}\text { Supply Chain } \\
\text { Management }\end{array}$ & $\begin{array}{l}\text { When the supply chain is tracked with BCT, the handover of a product from } \\
\text { manufacture to sale between suppliers, manufacturers, retailers and } \\
\text { consumers can be documented, creating a permanent product history. In this } \\
\text { way, it may be possible to significantly reduce time delays, additional costs } \\
\text { and human errors that currently hinder operations. By using smart contracts, } \\
\text { automated control and financial flows can be realized during the movement } \\
\text { of a product on the chain. Customers can also have reliable information about } \\
\text { the arrival process of the product they bought (Usta and Dogantekin, } \\
\text { 2018:61). }\end{array}$ \\
\hline
\end{tabular}

\subsection{Impacts of Blockchain Technology}

Numerous case studies have been conducted to understand the impact of BCT on key supply chain 
objectives such as cost, quality, transparency, trust, risk reduction, sustainability and flexibility. Blockchain provides many benefits for different stakeholders in the supply chain. The impacts of BCT especially in supply chain management is summarized in Table 4:

\section{Table 4. Impacts of Blockchain Technology}

\begin{tabular}{|c|c|}
\hline \multicolumn{2}{|r|}{ Functional Impacts } \\
\hline $\begin{array}{l}\text { Transparency and } \\
\text { auditability }\end{array}$ & $\begin{array}{l}\text { BC can show real-time product updates. Where the product is, who produced it, } \\
\text { how it was produced and the scheduled delivery time can be seen. As each } \\
\text { transaction is recorded sequentially in the BC, a permanent audit trail is provided } \\
\text { that can verify the authenticity of the product and be traced through the chain of } \\
\text { custody (Accenture, 2018:7-8). }\end{array}$ \\
\hline Efficiency & $\begin{array}{l}\text { Efficiency gains can be achieved in reducing manual processes and duplications } \\
\text { for data validation and reconciliation between parties (Accenture, 2018:5). }\end{array}$ \\
\hline $\begin{array}{l}\text { Improved data } \\
\text { quality }\end{array}$ & $\begin{array}{l}\text { Smarter and more accessible data and market insights are provided by immutable } \\
\text { product-process connections (Lezoche et al., 2020:6). }\end{array}$ \\
\hline $\begin{array}{l}\text { Product } \\
\text { traceability }\end{array}$ & $\begin{array}{l}\text { With the globalization of trade, supply chains are becoming more and more } \\
\text { complex and it is becoming increasingly difficult to trace products. BC provides } \\
\text { end-to-end traceability in the supply chain. All members of the chain agree on } \\
\text { every transaction, once consensus is reached, the permanent record cannot be } \\
\text { changed (Galvez et al., 2018:223-26). }\end{array}$ \\
\hline \multicolumn{2}{|r|}{ Economic Impacts } \\
\hline Finance & $\begin{array}{l}\text { Small and medium-sized producers often face problems when they need credit, } \\
\text { due to lack of trust and knowledge. Blockchain can help supply chain stakeholders } \\
\text { access insurance and financing resources by providing a much higher level of } \\
\text { certainty about data (Accenture, 2018:9-10). }\end{array}$ \\
\hline $\begin{array}{l}\text { Cost savings and } \\
\text { revenue growth }\end{array}$ & $\begin{array}{l}\text { Savings can be achieved through transparency and certainty of product } \\
\text { movements, finance and credit facilities, and streamlined operations. Decreased } \\
\text { transaction costs, elimination of information differences between stakeholders, } \\
\text { fairer pricing, new product and market development can be achieved. }\end{array}$ \\
\hline $\begin{array}{l}\text { Contract } \\
\text { management }\end{array}$ & $\begin{array}{l}\text { BC can share data such as inventory more efficiently, making it easier for a } \\
\text { company to manage different suppliers and contracts. Shared inventory and } \\
\text { automated purchase orders on the BC can accelerate product movements } \\
\text { throughout the supply chain, reduce the risks of product spoilage, and meet } \\
\text { consumer demands more efficiently (Accenture, 2018:9). Contract execution and } \\
\text { slow payments can lead to unnecessary waiting and penalties throughout the } \\
\text { supply chain. Smart contracts or cryptocurrency-based transactions can save time } \\
\text { and resources (Hancock, 2019:29). }\end{array}$ \\
\hline \multicolumn{2}{|r|}{ Business Impacts } \\
\hline Marketing tool & $\begin{array}{l}\text { Since } \mathrm{BC} \text { is completely transparent and participants can control the products } \\
\text { inside, they can be used to improve the image and reputation of institutions, stand }\end{array}$ \\
\hline
\end{tabular}




\begin{tabular}{|c|c|}
\hline & $\begin{array}{l}\text { out from the competition, increase loyalty among existing customers and attract } \\
\text { new ones (Galvez et al., 2018:226). }\end{array}$ \\
\hline $\begin{array}{l}\text { New business } \\
\text { models and } \\
\text { sustainable } \\
\text { product } \\
\text { differentiation }\end{array}$ & $\begin{array}{l}\text { BC can automate purchasing by changing the functions of intermediaries in global } \\
\text { trade. Just as e-commerce is an alternative to physical stores, BC can enable } \\
\text { manufacturers to reach consumers directly. Transparent, real-time data on product } \\
\text { movements can create a collaborative approach to global trade, reduce costs and } \\
\text { increase efficiency (Accenture, 2018:9-10). }\end{array}$ \\
\hline \multicolumn{2}{|r|}{ Technological Impacts } \\
\hline $\begin{array}{l}\text { Streamlined } \\
\text { operations }\end{array}$ & $\begin{array}{l}\text { Applications on the BC platform can streamline processes by moving data to the } \\
\text { BC through human input or an automated process or technology, for example an } \\
\text { automated sensor that measures the temperature in a transport truck (Accenture, } \\
\text { 2018:8). }\end{array}$ \\
\hline $\begin{array}{l}\text { Operations without } \\
\text { intermediaries }\end{array}$ & $\begin{array}{l}\text { Smart contracts can validate the terms of a contract between counterparties } \\
\text { without the need for a human as an intermediary. With users' confidence that } \\
\text { transactions will be executed exactly according to contract terms, the need for a } \\
\text { trusted third party can be eliminated. }\end{array}$ \\
\hline \multicolumn{2}{|r|}{ Environmental and Social Impacts } \\
\hline Waste reduction & Waste reduction can be achieved with improved traceability. \\
\hline $\begin{array}{l}\text { Reduction of } \\
\text { stakeholder risk }\end{array}$ & $\begin{array}{l}\text { Risks arising from counterfeit products and low-quality components can be } \\
\text { reduced. }\end{array}$ \\
\hline Brand image & $\begin{array}{l}\text { Quickly identifying the source of a food contamination can help protect a } \\
\text { company's brand image and mitigate the negative impact of criticism from the } \\
\text { media (Galvez et al., 2018:226). }\end{array}$ \\
\hline $\begin{array}{l}\text { Customer } \\
\text { satisfaction }\end{array}$ & Ensuring product safety and quality can increase customer satisfaction. \\
\hline
\end{tabular}

\subsection{Challenges of Implementing Blockchain Technology}

While blockchain technology is expected to bring many benefits to traditional supply chains as it continues to evolve, there are organizational, technological, legal, environmental and social challenges that must be addressed before the technology reaches maturity to ensure its scalability and accessibility (FAO, 2018:21). As blockchain technology is quite difficult and expensive to implement, these challenges outlined in Table 5 pose a significant threat to the implementation of BCT.

\section{Table 5. Challenges of Implementing Blockchain Technology}

\begin{tabular}{|c|c|}
\hline & Organizational Challenges \\
\hline $\begin{array}{l}\text { The difficulty of } \\
\text { bringing the entire } \\
\text { supply chain } \\
\text { together }\end{array}$ & $\begin{array}{l}\text { Sufficient number of manufacturers and supply chain stakeholders must be } \\
\text { included in the system for effective use of the blockchain system (Hancock, } \\
\text { 2019:10). Engagement challenges may arise due to lack of technical competence } \\
\text { and awareness of BCT, successful organizations not wanting to change their }\end{array}$ \\
\hline
\end{tabular}




\begin{tabular}{|c|c|}
\hline & $\begin{array}{l}\text { current revenue models, resistance from supply chain intermediaries, and } \\
\text { resistance of existing supply chain stakeholders to share valuable data in real- } \\
\text { time in a decentralized and shared database. }\end{array}$ \\
\hline Cultural adoption & $\begin{array}{l}\text { BCT requires transparency of information, which will require stakeholders to } \\
\text { adopt a new social governance model (Kim et al., 2018:339). In particular, small } \\
\text { SMEs (small-to medium enterprises) may experience the problem of not adopting } \\
\text { technology (Kamilaris et al., 2018:12). }\end{array}$ \\
\hline $\begin{array}{l}\text { Distrust between } \\
\text { organizations }\end{array}$ & $\begin{array}{l}\text { The size of the chain, as well as its homogeneity fosters trust between } \\
\text { organizations. If the chain has a major partner and its rules are followed, this can } \\
\text { cause trust problems between organizations (Kayıçı and Subramanian, } \\
\text { 2018:259). }\end{array}$ \\
\hline $\begin{array}{l}\text { High Cost of } \\
\text { Implementation }\end{array}$ & $\begin{array}{l}\text { Cost savings have been the most important factor in companies' adoption of new } \\
\text { technologies. BCT currently requires high capital costs, as the Proof of Work } \\
\text { algorithm used by most Blockchains requires significant computing power for } \\
\text { their transactions (Kay1kç1 and Subramanian, 2018:260). }\end{array}$ \\
\hline \multicolumn{2}{|r|}{ Legal Challenges } \\
\hline $\begin{array}{l}\text { Lack of Legislation } \\
\text { and Regulation }\end{array}$ & $\begin{array}{l}\text { Changing the standards and applying a completely new system requires legal } \\
\text { regulations to be made (Kayıçı and Subramanian, 2018:258). }\end{array}$ \\
\hline $\begin{array}{l}\text { Uncertain } \\
\text { regulation }\end{array}$ & $\begin{array}{l}\text { There is a need to comply with laws and regulations, it is also risky that new laws } \\
\text { and regulations may impose restrictions on the blockchain. }\end{array}$ \\
\hline \multicolumn{2}{|r|}{ Environmental Challenges } \\
\hline $\begin{array}{l}\text { Large energy } \\
\text { consumption }\end{array}$ & $\begin{array}{l}\text { Running the Bitcoin software can use almost as much power as the entire country } \\
\text { of Denmark in terms of electricity consumption. As blockchain is expected to } \\
\text { gain more and more popularity, its maintenance poses a major environmental } \\
\text { challenge (European Commission, 2020:33). }\end{array}$ \\
\hline \multicolumn{2}{|r|}{ Technological Challenges } \\
\hline $\begin{array}{l}\text { Infrastructure and } \\
\text { capacity }\end{array}$ & $\begin{array}{l}\text { It can only be implemented as long as there is an internet connection, which may } \\
\text { be a problem in developing countries (Lezoche et al., 2020:6). }\end{array}$ \\
\hline Interoperability & $\begin{array}{l}\text { Blockchain alone is not enough, it needs to be used and integrated with other } \\
\text { digital technologies such as EDI, RFID, NFC tags, wireless sensor networks, } \\
\text { ERP, data warehouses or IoT (Kayıçı and Subramanian, 2018:258). }\end{array}$ \\
\hline $\begin{array}{l}\text { The need for } \\
\text { significant changes } \\
\text { to existing systems }\end{array}$ & $\begin{array}{l}\text { For the transition to a blockchain-based system, organizations may need to } \\
\text { integrate their existing systems with blockchain or completely replace their old } \\
\text { systems (European Commission, 2020:38). }\end{array}$ \\
\hline $\begin{array}{l}\text { Absence of } \\
\text { Standards }\end{array}$ & $\begin{array}{l}\text { The necessary standards and regulatory protocols for data transfer and security } \\
\text { issue are not yet fully available (Kayıçı and Subramanian, 2018:258). }\end{array}$ \\
\hline $\begin{array}{l}\text { Transaction } \\
\text { capacity-scalability } \\
\text { issue }\end{array}$ & $\begin{array}{l}\text { One of the main technical challenges with blockchain is the question of how } \\
\text { many transactions per second it can handle (European Commission, 2020:30). }\end{array}$ \\
\hline
\end{tabular}




\begin{tabular}{|c|c|}
\hline $\begin{array}{l}\text { Consensus } \\
\text { Problem }\end{array}$ & $\begin{array}{l}\text { In a public blockchain, the consensus rule creates the problem of low transaction } \\
\text { volume and block generation rate. Currently, the latency for updates is of } 15 \\
\text { seconds on average for a new block to be written to the Ethereum blockchain. } \\
\text { The latency is proportional to the amount of traffic on the blockchain; potential } \\
\text { bottlenecks can result in increased economic costs of mining operations. } \\
\text { Although scaling solutions have been launched to increase transaction speed - } \\
\text { there is no precise estimate of when public Blockchains can process thousands of } \\
\text { transactions per second like OLTP systems (Kim et al., 2018, s. 339). }\end{array}$ \\
\hline \multicolumn{2}{|r|}{ Social Challenges } \\
\hline $\begin{array}{l}\text { Lack of necessary } \\
\text { technical skills and } \\
\text { expertise }\end{array}$ & $\begin{array}{l}\text { Smart contract engineering, solutions architecture, cryptography and distributed } \\
\text { network engineering are the most needed technical skills. Crypto economics, law } \\
\text { and business development are the most needed non-technical skills. BC-specific } \\
\text { and multidisciplinary profiles are hard-to-find and most valuable expertise in the } \\
\text { market (EU Blockchain Observatory and Forum, 2020:71). }\end{array}$ \\
\hline $\begin{array}{l}\text { Limited education } \\
\text { and training } \\
\text { platforms }\end{array}$ & $\begin{array}{l}\text { In addition to the general lack of awareness about BC, educational platforms are } \\
\text { not yet widespread. For blockchain adoption, it must first be understood } \\
\text { (Kamilaris et al., 2018:10). For this reason, education and training platforms } \\
\text { should be expanded. }\end{array}$ \\
\hline $\begin{array}{l}\text { Difference in } \\
\text { understanding }\end{array}$ & $\begin{array}{l}\text { There is a difference in understanding between policy makers and technical } \\
\text { experts on how ICT and transactions should be used (Kamilaris et al., 2018:10). }\end{array}$ \\
\hline The digital divide & $\begin{array}{l}\text { The most obvious limitation of BC is that access to a device with internet access } \\
\text { is required to add or view data in a BC (Hancock, 2019:9) }\end{array}$ \\
\hline Error in data entry & $\begin{array}{l}\text { In BC, records are immutable, but there is still a risk of data being skipped or } \\
\text { incorrect data entered, either intentionally or unintentionally. Even when false } \\
\text { data is added to the chain, BC provides an advantage over traditional supply chain } \\
\text { methods by providing a clearer, faster way to track and identify parties } \\
\text { responsible for false data (Hancock, 2019:10). }\end{array}$ \\
\hline $\begin{array}{l}\text { Low technology } \\
\text { adoption rate }\end{array}$ & $\begin{array}{l}\text { The higher the technology adoption rate for new technologies, the higher the } \\
\text { acceptance and implementation (Kayıçı and Subramanian, 2018: 260). }\end{array}$ \\
\hline
\end{tabular}

\section{CONCLUSION}

Blockchain, which is expected to change business models and ways of doing business, is being researched by different sectors and companies. There are many sectors that can benefit from the advantages of BCT, some of them are Education, Energy, Public, Finance, Health-Pharmaceutical and Agri-Food sectors.

With the use of BCT, providing coordination and cooperation between stakeholders, data integration and product traceability, especially global and complex supply chain the supply chain can be improved. Full traceability of data in the BC is ensured, with the distributed structure of the technology and high security, it can be ensured that the data is not changed, automation is provided with smart 
contracts, speed and efficiency increases, bureaucracy is simplified, intermediaries can be eliminated, and costs can be reduced.

While BCT continues to evolve, it is expected to bring many benefits to traditional supply chains such as transparency, auditability, efficiency, product traceability, security and customer satisfaction. However, in order to ensure the scalability and accessibility of technology, there are organizational, technological, legal, environmental and social challenges that must be addressed before it reaches maturity. These challenges pose a significant threat to the implementation of BCT, as it is quite difficult and expensive. To reduce barriers to use, more investment should be made by governments in research and innovation, education and training to produce and demonstrate evidence of the potential benefits of BCT. One of the biggest obstacles to the adoption of BCT is legal uncertainty, and the uncertainty should be eliminated by making regulations.

When at the applications in Turkey are examined, Blockchain Turkey Platform - Manufacture, Logistics and Transportation Working Group's Blockchain-based "Supplier Recognition Platform" solution, it is aimed for customers and suppliers to find each other easily, to prepare and verify the necessary information and documents quickly, to increase efficiency, and to prevent mistakes caused by forgery or errors. The stakeholders of the system to be created will be public institutions, financial service providers, unions, chambers and associations, private companies, SMEs, banks, logistics companies, information technology providers and investors.

Distributed agri-food supply chains, which include many stakeholders such as farmers, transport companies, distributors and retailers, are also sectors that can benefit from BCT. In the agri-food supply chain, BC provides transparency, allowing consumers to obtain reliable information about the source of the goods, and epidemics can be prevented by quickly tracking contaminated food in risky situations. In Turkish food retail sector, Migros has decided to use BCT to ensure supply chain security, transparency and the traceability of fruit and vegetable products from farm to store.

The contribution of this study to the literature is to provide a review of BCT in the time period of 2010-2019. First of all, academic and sectoral resources were examined and basic information about blockchain technology and smart contracts was presented. Then, in order to show that BCT does not consist only of cryptocurrencies, its application areas in different sectors, business impacts and implementation challenges are examined and suggestions are made for the adoption of blockchain technology. In this study, the focused sectors were restricted to Education, Energy, Public, Finance, Health-Pharmaceutical and Agri-Food. Applications in different industries can be studied and real applications can be further explored to gain in-depth knowledge of the application and benefits of $\mathrm{BCT}$. In future studies, the application of BC in the agricultural sector, which is of great importance with its share in employment in Turkey, can be examined. BCT can be researched as a transparency, 
traceability and food safety solution in supply chain management and especially in agri-food supply chains, and a proposal for a blockchain supported conceptual reference process model that can be applied in agriculture-food supply chains in Turkey can be developed.

\section{REFERENCES}

Accenture (2018), “Tracing the Supply Chain: How Blockchain Can Enable Traceability in the Food industry".

Alladi, T., Chamola, V., Parizi, R. M. and Choo, K. R. (2019), "Blockchain Applications for Industry 4.0 and Industrial IoT: A Review", IEEE Access, 7, 176935-51.

Amir Latif, R. M., Shah, S. U. A., Iqbal, S., Farhan, M., Rizwan O., and Ijaz, F. (2019), "Blockchain Transforms the Retail Level by Using a Supply chain Rules and Regulation", 2019 2nd International Conference on Communication, Computing and Digital Systems, C-CODE 2019, 264-69, Islamabad: IEEE.

Andoni, M., Robu, V., Flynn, D., Abram, S., Geach, D., Jenkins, D., Mccallum, P., and Peacock, A. (2019), "Blockchain technology in the energy sector: A systematic review of challenges and opportunities", Renewable and Sustainable Energy Reviews, 100:143-74.

Azzi, R., Chamoun, R. K., and Sokhn, M. (2019), "The power of a blockchain-based supply chain", Computers and Industrial Engineering, 135:582-92.

BCTR (2019), "Blokzinciri Teknolojisi Terminoloji Çalışması- Hukuk, Düzenlemeler ve Kamu İlişkileri Çalışma Grubu”.

Bennett, R. M., Pickerıng, M., and Sargent, J. (2019), “Transformations, transitions, or tall tales? A global review of the uptake and impact of NoSQL, blockchain, and big data analytics on the land administration sector", Land Use Policy, 83:435-48.

Biswas, B. and Gupta, R. (2019), "Analysis of barriers to implement blockchain in industry and service sectors", Computers and Industrial Engineering, 136(July):225-41.

Blasetti, R. (2017). "Blockchain For Business, Should You Care?" https://blockgeeks.com/blockchain-for-business/, (Access: 24.10.2020).

Casino, F., Kanakaris, V., Dasaklis, T. K., Moschuris, S., and Rachaniotis, N.P. (2019), Modeling food supply chain traceability based on blockchain technology", IFAC-PapersOnLine, 52(13):272833.

Croxson, A., Sharma, R. S., and Wingreen, S. (2019), "Making Sense of Blockchain in Food SupplyChains. Australasian Conference on Information Systems", 97-107, Perth Western Australia.

Deloitte (2018), "New Tech on the Block: Planning for Blockchain in the Retail and Consumer Packaged Goods industries".

European Commission (2020), "Study on Blockchains: Legal, Governance and Interoperability Aspects", European Commission.

EU Blockchain Observatory and Forum (2020), "2018-2020 Conclusions and Reflections".

FAO (2018), "Emerging Opportunities for the Application of Blockchain in the Agri-food Industry", Rome and Geneva. 
FAO (2020), "The State of Agricultural Commodity Markets. Agricultural Markets and Sustainable Development: Global Value Chains, Smallholder Farmers and Digital Innovations”, Rome.

Galvez, J. F., Mejuto, J. C. and Simal-Gandara, J. (2018), "Future challenges on the use of blockchain for food traceability analysis", Trends in Analytical Chemistry, 107:222-32.

Gerdan, G. (2019), “Blokzincir Teknolojisiyle Gida Güvenliği ve Yumurta Sektörü İçin Örnek Bir Uygulama”, Yüksek Lisans Tezi, Marmara Üniversitesi Sosyal Bilimler Enstitüsü, İstanbul.

Hancock, C. N. (2019), "The Integration of Blockchain Technology to the Beef Industry-A Comparative Analysis".

Kamble, S. S., Gunasekaran, A., and Sharma, R. (2019), Modeling the blockchain enabled traceability in agriculture supply chain”, International Journal of Information Management, 1-16.

Kamilaris, A., Fonts, A. and Prenafeta-Boldú, F.X. (2018), "The Rise of the Blockchain Technology in Agriculture and Food Supply Chain", Barcelona.

Kayıkçı, Y. and Subramanian, N. (2018), "Feasibility of Food Loss Reduction with Blockchain in the Emerging Economy Context”, 23rd International Symposium on Logistics (ISL 2018) - Big Data Enabled Supply Chain Innovations, 255-62.

Kim, M., Hilton, B., Zach Burks, and Jordan Reyes. (2018), "Integrating Blockchain, Smart ContractTokens, and IoT to Design a Food Traceability Solution”, 2018 IEEE 9th Annual Information Technology, Electronics \& Mobile Communication Conference, 2018, 335-40, Vancouver: IEEE.

Knezevic, D.. (2018), "Impact of Blockchain Technology Platform in Changing the Financial Sector and Other Industries", Montenegrin Journal of Economics, 14(1):109-20.

Lezoche, M., Hernandez, J. E., Diaz, M. Panetto, H., and Kacprzyk, J. (2020), “Agri-food 4.0: A survey of the supply chains and technologies for the future agriculture", Computers in Industry, 117. Marketsandmarkets. (2020), "Blockchain Market Size, Growth, Trends and Forecast to 2025", https://www.marketsandmarkets.com/Market-Reports/blockchain-technology-market-

90100890.html, (Access: 11.10.2020).

McKinsey. 2018, "Blockchain beyond the hype: What is the strategic business value?" https://www.mckinsey.com/business-functions/mckinsey-digital/our-insights/blockchain-beyondthe-hype-what-is-the-strategic-business-value, (Access: 11.10.2020).

OECD. (2018), "Blockchain and its Use in the Public Sector".

Olsen, P., Borit, M. and Syed, S.. (2019), "Applications, limitations, costs, and benefits related to the use of blockchain technology in the food industry".

PwC "Global Blockchain Survey", https://www.pwc.com/gx/en/industries/technology/blockchain/blockchain-in-business.html, (Access: 06.10.2020).

Tanrıverdi, M., Uysal, M. and Üstündağ, M. T. (2019), "Blokzinciri Teknolojisi Nedir ? Ne Değildir ?: Alanyazın İncelemesi”, Bilişim Teknolojileri Dergisi, 12(3):203-17.

Usta, A. and Doğantekin, S. (2018), "Blockchain 101 v2", BKM.

World Economic Forum. (2019), "Inclusive Deployment of Blockchain for Supply Chains: Part 1- 
Introduction".

World Economic Forum. (2020), "Redesigning Trust: Blockchain Deployment Toolkit - Supply Chain Focus".

Yiannas, F.. (2018), “A New Era of Food Transparency Powered by Blockchain. Innovations: Technology, Governance, Globalization”, 12(1-2):46-56.

Yılmaz, R. (2019), "Ürünlerin Tedarikçiden Tüketiciye Ulaşmasını Takip Edecek bir Blok Zinciri Sisteminin Tasarlanması", Yüksek Lisans Tezi, İstanbul Üniversitesi Fen Bilimleri Enstitüsü, İstanbul.

Zhang, C., Gong, Y. Brown, S. and Li, Z. (2019), “A content-based literature review on the application of blockchain in food supply chain management”, The 26th EurOMA Conference, Helsinki.

Zhao, G., Liu, S. Lopez, C., Lu, H., Elgueta, S., Chen, H., and Boshkoska, B. M. (2019), Blockchain technology in agri-food value chain management: A synthesis of applications, challenges and future research directions", Computers in Industry, 109:83-99. 